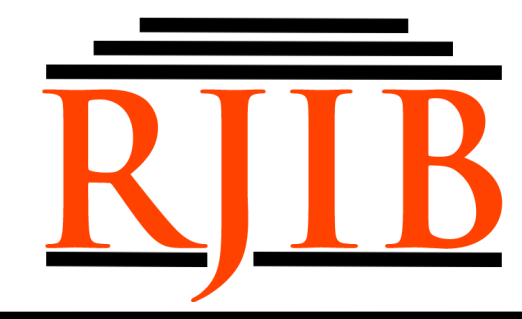

RETORIKA: Jurnal Ilmu Bahasa

Vol. 5, No. 2 Oktober 2019, Page 138-147

\title{
The Translation of Reiteration
}

\author{
Komang Astiari, I Wayan Budiarta and Agus Darma Yoga Pratama \\ Magister of Linguistic, Universitas Warmadewa, Denpasar, Bali-Indonesia \\ astiari_komang@yahoo.co.id
}

\begin{tabular}{|l|l|}
\hline Received: 25/04/2019 Revised: 20/06/2019 & Published: 15/10/2019 \\
\hline How to cite (in APA style): & \\
Astiari. K., Budiarta. I. W., \& Pratama, A. D. Y. (2019). The Translation of Reiteration. RETORIKA: Jurnal Ilmu Bahasa, \\
5(2), 138-147. doi: http://dx.doi.org/10.22225/jr.5.2.1093.138-147
\end{tabular}

\begin{abstract}
Lexical cohesion has been a serious issue as it is one of the important features in a text. Every writer must consider kinds of lexical devices in writing a text and so do the translator. The main problem in translating the lexical cohesion devices is the different structure between two languages. One device can be applied in one language but not in other language. This journal analyzed the translation of reiteration as part of lexical cohesion devices appeared in the short stories The Black Cat and The Cask of Amontillado written by American writer, Edgar Allan Poe. The short stories were translated by two Indonesian translators namely Anton Kurnia and Shinta Dewi. This research is conducted to share the practice of translating literature works especially a short story which contains a lot of lexical cohesion devices and to give contribution to the development of translation as part of linguistic studies. In doing the research, qualitative and quantitative method is applied including observation, interviews, or document reviews. In the source text, it was found 120 of lexical cohesion devices in the short story "The Cask of Amontillado" and 187 lexical cohesion devices in the short story "The Black Cat". The results obtained from this research were that Anton Kurnia translated $73 \%$ of lexical cohesion devices in the source language into the target language. Meanwhile, Shinta Dewi translated $94 \%$ of lexical cohesion devices in the source text to the target text.
\end{abstract}

Keywords: lexical cohesion, reiteration translation, short stories

\section{INTRODUCTION}

In the translation work, the translators should not only be aware of the methods or techniques he/ she applied but also kinds of texts that are going to be translated. The similar response of the target readers to the original readers seem to be the most important thing to be achieved. However, the fact is that the translated texts cannot be better than the original since both languages have different cultures.

Different texts acquire different methods for they were made for different purpose. One kind of texts, narrative text is an essay that presents a series of events and is arranged chronologically through stories and good stories. The aim is to entertain the readers with fictional or nonfictional series completed with aesthetic experience. The translation of literary works requires a high sensitivity of the translators and the original aesthetic elements must be maintained. It is like translating the same scenario in the source texts to the target texts and presenting the same emotions as in the original one as well as the stylistic features of the source language. Due to the objective, proper cohesion devices are needed in order to compile the good ones. There are two kinds of cohesions namely grammatical and lexical cohesion (Halliday \& Hasan, 1985). Grammatical cohesion is detected by grammatical structures tied to each other. Meanwhile, lexical cohesion is selection of lexis that are related in some way to those that have gone before. (Larson, 1998) stated that pronouns, roles, conjunctions, chaining, verb morphology, and orders are the features which can give cohesion to the texts. In addition, 
contiguous events and semantic domain of concepts could also give cohesion. Semantic domain does not refer to using the same form or referring to the same specific item over and over, but rather to the fact that things being referred to are from the same domain, center on the same topic or have certain semantic components in common, for examples; school, teacher, student, classroom, homework, ,library, etc.

Based on (Tanskanen, 2006) which refers to (Halliday \& Hasan, 1976), there are three types of lexical cohesion devices; reiteration, collocation, and lexical chains. Reiteration is divided into six devices, they are simple repetition, complex repetition, substitution, equivalence, generalization, specification, co-specification, and contrast. Three types of collocation are ordered-set collocation, activity-related collocation, and elaborative collocation. Lexical chains have two types they are identity chain and similarity chain.

The focus of this study is to detect the reiteration devices found in the short stories written by Edgar Allan Poe and how they were translated into Indonesian by two Indonesian translators. This study is conducted to compare how the two Indonesian translators rendered the lexical cohesion device, specifically reiteration. There were many researchers who did the same investigation, among them; there were three researches that are going to be stated in this study.

(Morris \& Hirst, 1991) in their research entitled "Lexical Cohesion Computed by Thesaural Relations as an Indicator of the Structure of Text" showed that lexical cohesion is the results of chains of related words that contribute to the continuity of lexical meaning. The lexical chains were being computed in order to correspondence the structure of the text. Determining the structure of text is an essential step in determining the deep meaning of the text. For computing lexical chains, Thesaurus has been used as the major knowledge. Since the lexical chains are computable, and exist in non-domain-specific text, they provide a valuable indicator of text structure. The lexical chains also provide a semantic context for interpreting words, concepts, and sentences. This study gave a contribution in the nature of lexical chains to give cohesion to the text, but there was no comparison to the non-computed work in the translation of lexical chains.

$$
\text { (Lotfipour-Saedi, 1997) in his research }
$$

entitled "Lexical Cohesion and Translation Equivalence" investigated the notion of translation equivalence in terms of lexical cohesion. There were three points to be analyzed, they were type of lexical strategies employed by the SL discourse producer, the nature of the cohesive network as well as the semantic structure that arised among the lexical nodes. Based on the study, it was explained that a text rather than a sentence is the unit of communication and negotiation. They can be achieved within the framework of a text. There were some features found, but among all of those features which contribute to the texture of a text, the argumentation came to cohesion as the most important part in the text. It affects the comprehension process. However, the translation of the lexical cohesion was not elaborated in detail.

Meanwhile, (Nassar, 2014) in his research, showed the importance of cohesion in the translation work and the difficulties that might be found in translating the cohesion. It was explained in the study that cohesion as a part of the whole text, cannot stand alone. As a result, the cohesion devices must be one of the consideration in translating the work in order to create a good result of the text in the target language. This research investigated the grammatical and lexical cohesion both in the source text and target text. Several theories of translated were adopted such as theory of semantic and communicative translation by (Newmark, 1988), theory of meaning-based translation by Larson, and theory of word-perword and literal translation by (Catford, 1965). The result of the research showed that the lexical cohesion could create a good narrative text. As the data, it used the English novel written by June Austen entitled Pride and Prejudice into Arabic. This study gave a contribution since it also investigated the cohesion of a text due to the availability of lexical cohesion but the writer did not highlight the translation of the devices clearly and no comparison of two translators.

\section{METHOD}

The sources to be analyzed is the English short stories written by (Poe, 2004). This research is both a quantitative and qualitative descriptive study with a case study design embedded and oriented to product translation. This research is a single case study because the objective is to analyze the lexical cohesion devices in the form of words or phrases and a comparison of the shifts in the type of cohesion 
that occurred in the Edgar Allan Poe's short stories. This study used content analysis in collecting the data by carrying out these activities of classifying the utterances consisting lexical cohesion devices in SL, writing the data that have been classified into tables, comparing the translation results of the two Indonesian translators, classifying the translation of the lexical cohesion devices in the TL into tables.

\section{RESULT AND DISCUSSION}

After reading the short stories entitled "The Black Cat" and "The Cask of Amontillado", several lexical cohesion devices are detected and create a good narrative of the story. The total number of lexical cohesion devices detected in the short stories can be viewed in the table below, followed by the analyses of each finding.

Table 1

Number of lexical Cohesion

\begin{tabular}{ccc}
\hline & $\begin{array}{c}\text { The Cask of } \\
\text { Amontillado }\end{array}$ & The Black Cat \\
\hline $\begin{array}{c}\text { Total } \\
\text { number of } \\
\text { lexical } \\
\text { cohesion }\end{array}$ & 120 & 187 \\
\hline
\end{tabular}

Since short stories show a very short nature, events, numbers of actors and words, the capacity of the writer in making a smooth story must be take into consideration. Its purpose is to give a deep impression to the readers. The choice of lexical cohesion devices must be one of the important things to be the top concern. It can give a continuity to the story and is like a glue that stick words to words or clauses to clauses. In this study, the data were taken from two English short stories written by Edgar Allan Poe, an American writer with the tittle of "The Cask of Amontillado" and "The Black Cat". Poe, who was known as a writer, poet, editor, and an art curator; was the pioneer of a detective, horror, and science fiction genre of story. The two short stories were translated by two Indonesian translators namely Anton Kurnia (2004) and Shinta Dewi (2016). There were 120 lexical cohesion devices found in the story "The Cask of Amontillado" and 187 found in the story "The Black Cat". The translation of those devices were translated differently by the two translators, some were translated to be another types of lexical cohesion devices and some were not translated to be lexical cohesion devices and the variety can be seen in the following:

Reiteration is described as one kind of lexical cohesion which has a repetition of lexical item that can be understood by the sense of the earlier item and could establish the continuity of the story (Halliday \& Hasan, 1976). There are eight kinds of reiteration namely simple repetition, complex repetition, substitution, equivalence, generalization, specification, co-specification, and contrast.

Simple repetition as a repetition of word/ phrase/ clause in the next clause / sentence without any changing in the word class can be easily detected in the paragraph. The simple repetition was mostly applied in the short stories and they can be translated to be simple repetition as well in the target language as in the example below:

SL : I must not only punish but punish with impunity

TL :Tidak hanya aku harus menghukum, tapi aku juga menghukum tanpa aku sendiri mendapat hukuman (Shinta Dewi).

In the example above, The word punish in SL was repeated with an identical form and they are in one sentence. They were categorized as simple repetition because punish in the verb phrase must not only punish functions as a main verb and so do punish in the punish with impunity. In the TL, the translation was menghukum whereas it is categorized as a verb. It comes from the prefix me- and root hukum, therefore it forms verb menghukum. It was repeated using the same verb menghukum in the next clause, thus it was categorized as simple repetition as well.

Simple repetition can also be translated to be complex repetition as can be seen in the following example:

SL : The earliest indication I had of this was a low morning cry from the depth of the recess. It was not the cry of a drunken man.

TL : Aku mendengarnya menangis meratap. Itu bukan tangisan orang mabuk (Anton Kurnia).

In the SL, the word cry was being repeated in the next sentence. A low morning cry, the word cry in this noun phrase was considered to be noun. It comes after the modifier low and morning. the next sentence, the word cry in the it was not the cry was also a noun because it comes after the determiner the. Since these words were simply repeated with the same class, that is a noun, it was categorized as a simple repetition. In the TL, it became menangis and tangisan. In sentence aku mendengarnya menangis meratap the word 
menangis was considered to be verb, it comes from the prefix $m e$ - and root tangis and form a verb menangis. In the next sentence, the word cry was translated to be tangisan which is considered to be noun. The root tangis and suffix -an creates tangisan which is classified as a noun. There was a changing in the word class thus it is called complex repetition. In these data, the simple repetition in the SL was translated as complex repetition in the TL.

The next one, simple repetition can be translated to be substitution, equivalence, generalization, co-specification, and similarity chain. One of the examples can be seen in the following:

SL : And now I was wretched beyond the wretchedness of mere Humanity. And a brute beast-whose fellow I had contemptuously destroyed- a brute beast to work out for me...

TL : Sekarang aku sungguh sengsara melampaui kesengsaraan yang diderita manusia biasa. Dan seekor binatang kejamyang sesamanya pernah kubinasakan-binatang kasar yang membuat aku-seorang manusia... (Shinta Dewi).

The noun phrase a brute beast was simply repeated the same way without changing the word class. It is a noun phrase. Determiner $a$ and modifier brute followed by noun beast form a noun phrase. In the TL, it was translated to be binatang kejam and binatang kasar. Kejam means no mercy and sympathy. Meanwhile, kasar means impolite manner that can hurt someone's feeling. The synonymous words of binatang kejam and binatang kasar are classified as equivalence. Thus, the translation of simple repetition in this data was translated as equivalence.

Another type of reiteration is complex repetition that can be recognized as a repetition of word/ phrase/ clause with a changing in the word class. Some examples can be elaborated in the following:

SL : I continued, as my wont, to smile in his face, and he did not perceive that my smile now was at the thought of his immolation.

TL : Seperti biasa, aku selalu tersenyum padanya. Ia tak menyangka bahwa aku tersenyum karena memikirkan balas dendamku (Anton Kurnia).

In the SL, smile was repeated in the next clause. In the first clause, smile was classified as a verb, this is the base form of verb that comes after the particle to, but in the next clause, the word smile is classified as noun because it comes after determiner $m y$. As they belong to different classes, they create a complex repetition. In the TL, the verb smile was translated to be tersenyum is a verb, it comes from prefix ter- and root senyum, and this verb was repeated in the next clause. Tersenyum In this data is classified as a verb. In this data, the complex repetition was translated to be simple repetition.

SL : I replied to the yells of him who clamoured. I re-echoed -I aided-I surpassed them in volume and strength. I did this, and the clamourer grew still.

TL : Seketika Fortunato memekik dan menjerit-jerit. Jeritan ini keluar secara tibatiba dari tenggorokannya sehingga keributan itu sempat mengejutkanku dan membuatku terjajar ke belakang. Sejenak aku tahu apa yang harus aku lakukan. Aku gemetar.Lalu aku mendekati dinding dan balas meneriaki Fortunato. Setiap kali ia menjerit, aku memekik lebih keras. Ini berlangsung beberapa saat, lalu ia diam (Anton Kurnia).

Clamoured in the SL is classified into verb that form verb phrase and clamourer is classified into noun because suffix $-e r$ can form a noun. The translator translated the word clamoured into memekik, menjerit-jerit, and clamourer into diam. In the TL, Memekik means to let out a high-pitched loud voice (KBBI). Diam means there is no voice. That shows antonym which is classified into contrast. In this data, the complex repetition was translated to be contrast.

Moreover, complex repetition can also be translated to be equivalence, generalization, co-specification, and activity-related collocation.

Other types of reiteration found in the short stories is substitution, whereas it was translated to be simple repetition and substitution. The data can be seen as follows:

SL : to the character of the mark of white hair, of which I have spoken, and which constituted the sole visible difference between the strange beast and the one I had destroyed.

TL : Bulu-bulu putih inilah satu-satunya perbedaan antara kucing ini dengan kucing yang pernah kubunuh (Anton Kurnia).

The strange beast in the SL was not repeated in the next clause. Rather, the writer substituted this word with phrase the one. There was a replacement of one item by another one. In the TL, the word the strange 
beast was translated into kucing and the word the one was also translated to be kucing. This type is classified as simple repetition because word kucing in the kucing ini is classified as a noun, it is followed by determiner ini and kucing in the kucing yang pernah kubunuh is also a noun because it is followed by modifier yang pernah kubunuh. In this data, substitution was translated to be simple repetition.

SL : I continued my caresses, and, when I prepared to go home, the animal evinced a disposition to accompany me. I permitted it to do so.

TL : Saat aku akan pergi, kucing itu seperti ingin mengikutiku. Aku membiarkannya berbuat begitu (Anton Kurnia).

Based on the context of the story, the cat followed the main character everywhere for he loved his pet so much; he did not mind if the pet to do the activity of following him everywhere. The writer of the story chose the word so in the sentence I permitted it to do so. It is classified as substitution. In the TL, it was translated to be begitu as can be seen in the sentence aku membiarkannya berbuat begitu. In this sentence, begitu is also classified as substitution. It replaces the idea of kucing itu mengikutiku. In this data, substitution was translated to be substitution as well.

Furthermore, other type of reiteration that can be found in the short stories was equivalence. Equivalence is substitution of one item by synonym or near-synonym. The equivalence devices found in the SL were translated to be various lexical cohesion devices in the TL. It was detected 21 of equivalence devices found in the story entitled "The Black Cat" and 11 devices found in the story "The Cask of Amontillado". The equivalence devices in the SL were translated to be simple repetition, complex repetition, substitution, equivalence, generalization, and co-specification. The data found can be seen in the following:

SL : A very good joke, indeed-an excellent jest.

TL : Benar-benar lelucon hebat- lelucon istimewa (Anton Kurnia).

Joke is something said or done to provoke laughter (Webster's Collegiate Dictionary, 1993) and jest is an utterance intended to be taken as mockery or humor (Webster's Collegiate Dictionary, 1993). Both are classified as equivalence because they have a closed meaning and are called synonym. In the TL, the translator translated those words to be lelucon and it was repeated in the following phrase. It is classified as simple repetition because both words belong to the same class, that is a noun. Lelucon is followed by modifier hebat and istimewa. In this data, equivalence was translated to be simple repetition.

SL : I had completed the eight, the ninth, and the tenth tier. I had finished a portion of the last and the eleventh.

TL : Sudah kuselesaikan deretan dinding ke delapan, ke Sembilan, dan ke sepuluh. Akupun telah merampungkan deretan terakhir, yaitu kesebelas (Shinta Dewi).

The verb completed means finish making or doing and this verb is not repeated in the next sentence. The writer chose equivalent word finished which means to bring (a task or activity) to an end / complete. In the TL, the verb completed was translated to be kuselesaikan and the verb finished was translated to be merampungkan. The verbs selesaikan and merampungkan have similar meaning; to bring a task to an end. In this data, the equivalence was also translated to be equivalence.

SL : I hastened to make an end of my labour. I forced the last stone into its position.

TL : Aku segera menyelesaikan dinding itu. Kurapatkan batu terakhir pada tempatnya. Lalu aku merekatkannya dengan semen. Terakhir, aku menumpuk belulang menutupi dinding baru itu (Anton Kurnia).

In the above data, in the SL, the word hastened means be quick to do something. Based on the context of the story, the main character wanted to wall up Fortunato. It was full of emotion for he wanted to do a revenge, therefore he hastened to make an end of his labour. In the next sentence the word hastened is replaced by the equivalence word forced which means make a way through or into by physical strength, break open by force. They have similar in meaning therefore it is classified as equivalence. In the TL, these words were translated to be menyelesaikan and menumpuk. These words also have a collocation, that is to finish walling up Fortunato, so it is classified as a similarity chain. In this data, equivalence was translated to be similarity chain.

Generalization is the next type of reiteration that also could be found in the short stories and was rendered to be simple repetition and generalization. The data found can be seen as in the following: 
SL : I had so much of my old heart left, as to be at first grieved by this evident dislike on the part of a creature which had once so loved me. But this feeling soon gave place to irritation.

TL : Pada mulanya aku merasa sedih karena binatang yang tadinya mencintaiku jadi membenciku. Namun, rasa sedih itu segera berubah menjadi rasa sebal (Anton Kurnia).

In the SL, the word feeling is the hypernym word for grieved. The writer used the general word in the next sentence to give cohesion to the text. The translations of these words are sedih which was repeated in the next sentence. Sedih in the merasa sedih is classified as adjective because it comes after the causative verb merasa and sedih in the rasa sedih is also an adjective because it comes after the modifier rasa. In this data, the generalization was translated to be simple repetition.

SL : A draught of this medoc will defend us from the damps. "Here, I knocked off the neck of a bottle which I drew from a long fellows that lay upon the mould.

TL : Seteguk anggur merah ini akan melindungi kita dari kelembaban di bawah sini. "Aku memilih sebuah botol dari barisan bagian bawah di antara botol-botol yang berjejer sepanjang dinding (Anton Kurnia).

In these texts, both SL and TL applied generalization, whereas there were word bottle or botol-botol as the general idea of medoc and anggur merah. Bottle is the hypernym of medoc, botol-botol is the hypernym of anggur merah. Hypernymy enables the writer to look into and understand the relation within. In this data, generalization was translated to be generalization.

In contrary to generalization, specification is one item to be considered to be the hyponym word for the previous item. In the short story entitled "The Black Cat", there were 10 specification devices and in "The Cask of Amontillado", there 5 specification devices. Based on the data, the specification was translated to be simple repetition, complex repetition and specification.

SL : I was especially fond of animals, and was indulged by my parents with a great variety of pets.

TL : Aku terutama sangat menyayangi binatang, dan orangtuaku memanjakanku dengan membolehkan aku memelihara berbagai jenis binatang (Shinta Dewi).
In the SL, it could be seen that there were two words animals and pets. These two words have relationship; pets is the hyponym word for animals. There are many kinds of animals, they are farm animals, endangered animals, wild animals, pets, and so on. It is classified as specification. In the TL, they were translated into binatang and the translator repeated the same word in the next clause. Binatang in menyayangi binatang is classified as noun, it forms the verb phrase and acts as an object. Binatang in the berbagai jenis binatang is also classified as a noun because it comes after the modifier berbagai jenis. Therefore it is classified as simple repetition. In this data, specification was translated to be simple repetition.

SL : ...there came back into my spirit a half-sentiment that seemed. I went so far as to regret the loss of the animal and to look about me ...

TL : ...dan selama itu pula, rasa sesal kembali menyergapku. Sampai-sampai aku menyesal karena harus kehilangan binatang itu, dan mencari di sekitarku...(Anton Kurnia)

Sentiment in the SL means refined feeling, delicate sensibility (Webster's Collegiate Dictionary, 1993). It is defined as a sensitive feeling and the general idea of regret. In the TL, it shows repetition of sesal. The first sesal is a noun; it comes after the modifier rasa. The second one, sesal is functioned as a verb, prefix me-combined with root sesal will form a verb to create an active sentence. It is classified as complex repetition. In this data, specification was translated to be complex repetition.

Co-specification was showed by the two items that have the same general item and they could substitute to each other. In the short story entitled "The Black Cat", there were 7 cospecification devices in the story "The Cask of Amontillado", it was found 3\% of the devices. However, based on the data, all cospecification devices were translated to be cospecification as well.

SL : That the temor and hormor with which the animal inspired me, had been heightened by one of the merest chimaeras it would be possible to conceive.

TL : Rasa ngeri dan takut yang dibangkitkan kucing itu pada diriku disebabkan oleh bulu-bulu putih di badannya (Anton Kurnia).

In the SL, the words terror and horror are co-specification, since they can substitute to 
each other and they are hyponyms words for negative feeling. The translator translated those two words the same way by using cospecification, that was ngeri and takut. According to the context of the story, these two words could emphasize the main character's feeling about the cat. In this data, cospecification was translated to be cospecification.

The last type of reiteration is contrast. Contrast can be detected when two items have opposite meaning. Based on the data, in the story of "The Black Cat", it were found 3 contrast and in the story "The Cask of Amontillado", it was found 3 contrast. In the data, contrast was translated to be substitution and contrast.

SL : When reason returned with the morning-when I had slept off the fumes of the night's debauch..

TL : Aku sadar pagi harinya. Pengaruh alkohol telah lenyap. Tapi aku merasakan sesuatu-separuh takut dan separuh menyesalatas apa yang telah kulakukan (Anton Kurnia).

In the SL, the word morning means the time from sunrise to noon (Merriam: 757) and the word night means the time from dusk to dawn when no sunlight is visible. From the definition, it can be seen that those two words have contrast meaning. In the TL, it was only morning that was translated into pagi. The word night was not translated, but it was omitted in the next sentence as can be seen in the clause atas apa yang telah kulakukan. There was no explanation about when the action was taken place and what was happened but the reader could understand that it was happened at night (semalam) and what happened was a murder based on the context of the story. Ellipsis is also one kind of substitution.

SL : When it reached the house it domesticated itself at once, and became immediately a great favorite with my wife. For my own part, I soon found a dislike to it arising within me.

TL : Setibanya di rumah, si kucing langsung merasa berada di rumah sendiri, dan segera menjadi binatang kesayangan istriku. Perasaan tidak suka terhadap kucing itu segera muncul dalam diriku (Shinta Dewi).

In the SL, it could be found contrast words, they were favorite and dislike. These two words were translated to be kesayangan and tidak suka, whereas they are also contrast in meaning. Favorite means one that is treated or regarded with special favor or liking In the next clause, there was a word dislike which is the opposite of like. In the TL, the translator used contrast words as well. Kesayangan means fondness of something and tidak suka means a feeling of dislike. Both are classified as contrast since they are antonym words.

After analyzing all kinds of lexical cohesion devices translation, the result of how both translators rendered the devices can be viewed in the table below:

Table 2

"The Black Cat" Translated to be "Kucing Hitam" by Anton Kurnia

\begin{tabular}{|c|c|c|c|c|c|c|c|c|c|c|c|c|c|}
\hline \multirow[b]{2}{*}{$\begin{array}{c}\text { Lexical } \\
\text { Cohesion } \\
\text { Devices }\end{array}$} & \multicolumn{8}{|c|}{ Reiteration } & \multicolumn{3}{|c|}{ Collocation } & \multicolumn{2}{|c|}{ Lexical Chain } \\
\hline & 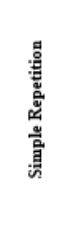 & 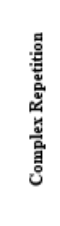 & 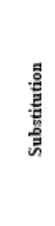 & 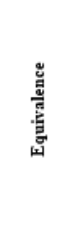 & 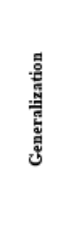 & 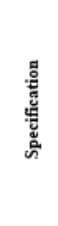 & 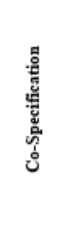 & 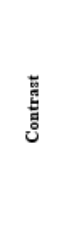 & 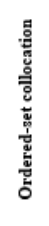 & 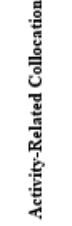 & 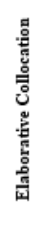 & 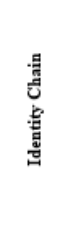 & 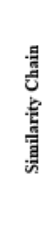 \\
\hline Reiteration & 13 & & 2 & 2 & 1 & & 1 & & & & & & 1 \\
\hline $\begin{array}{c}\text { Simple } \\
\text { Repetition }\end{array}$ & $7 \%$ & & $1 \%$ & $1 \%$ & $1 \%$ & & $1 \%$ & & & & & & $1 \%$ \\
\hline Complex & & & & 1 & 1 & & 1 & & & 3 & & & \\
\hline Repetition & & & & $1 \%$ & $1 \%$ & & $1 \%$ & & & $2 \%$ & & & \\
\hline Substitution & $\begin{array}{c}1 \\
1 \%\end{array}$ & & $\begin{array}{c}5 \\
3 \%\end{array}$ & & & & & & & & & & \\
\hline Eguivalence & 5 & 1 & 1 & 6 & & & 1 & & & & & & \\
\hline Equivalence & $3 \%$ & $1 \%$ & $1 \%$ & $3 \%$ & & & $1 \%$ & & & & & & \\
\hline Generalization & $\begin{array}{c}3 \\
2 \%\end{array}$ & & & & $\begin{array}{c}5 \\
3 \%\end{array}$ & & & & & & & & \\
\hline Specification & & & & & & $\begin{array}{c}9 \\
5 \%\end{array}$ & & & & & & & \\
\hline Co-Specification & & & & & & & $\begin{array}{c}4 \\
2 \%\end{array}$ & & & & & & \\
\hline Contrast & & & $\begin{array}{c}1 \\
1 \% \\
\end{array}$ & & & & & $\begin{array}{c}2 \\
1 \% \\
\end{array}$ & & & & & \\
\hline
\end{tabular}


Table 3

"The Black Cat" Translated to be "Kucing Hitam" by Shinta Dewi

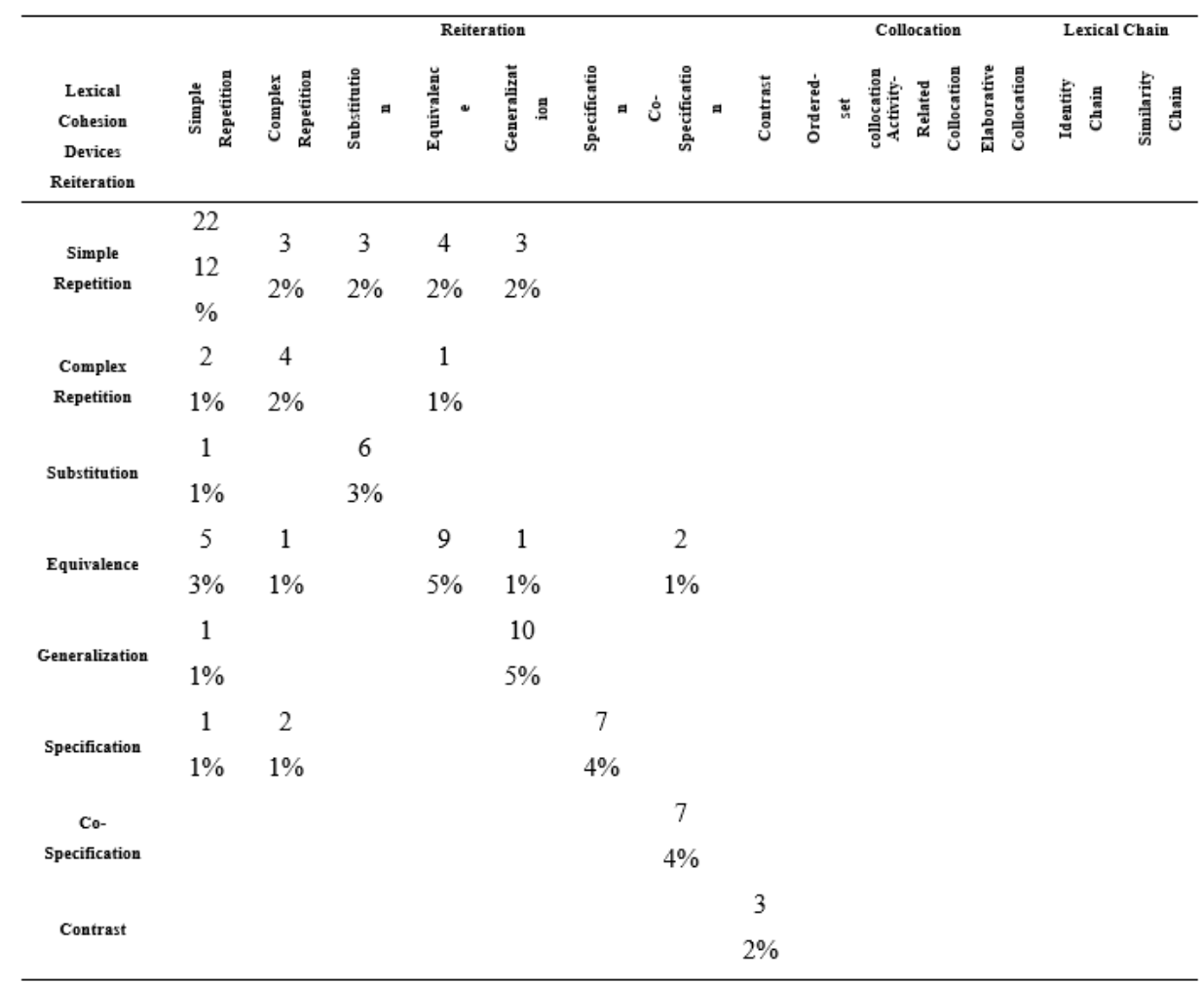

Table 4

"The Cask of Amontillado" Translated to be "Tong Amontillado" by Shinta Dewi

\begin{tabular}{|c|c|c|c|c|c|c|c|c|c|c|c|c|c|}
\hline \multirow[b]{2}{*}{$\begin{array}{l}\text { Lexical } \\
\text { Cohesion } \\
\text { Devices }\end{array}$} & \multicolumn{8}{|c|}{ Reiteration } & \multicolumn{3}{|c|}{ Collocation } & \multicolumn{2}{|c|}{ Lexical Chain } \\
\hline & 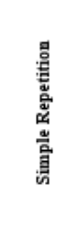 & 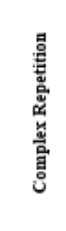 & $\begin{array}{l}\text { 量 } \\
\text { 意 } \\
\text { 意 }\end{array}$ & 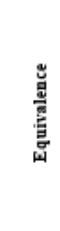 & 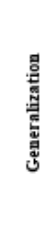 & 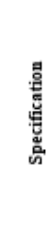 & 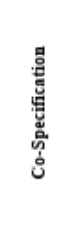 & 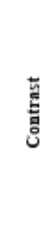 & 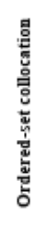 & 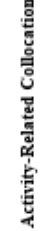 & 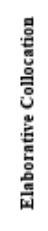 & 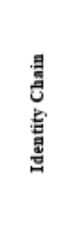 & 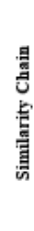 \\
\hline Reiteration & & & & & & & & & & & & & \\
\hline $\begin{array}{c}\text { Simple } \\
\text { Repetition }\end{array}$ & $\begin{array}{l}21 \\
18 \\
\%\end{array}$ & & $\begin{array}{c}1 \\
1 \%\end{array}$ & $\begin{array}{c}2 \\
2 \%\end{array}$ & & & & & & & & & \\
\hline $\begin{array}{c}\text { Complex } \\
\text { Repetition }\end{array}$ & $\begin{array}{c}1 \\
1 \%\end{array}$ & $\begin{array}{c}3 \\
3 \%\end{array}$ & & & & & & & & & & & \\
\hline Substitution & $\begin{array}{c}2 \\
2 \%\end{array}$ & & $\begin{array}{l}18 \\
15 \\
\%\end{array}$ & & & & & & & & & & \\
\hline Equivalence & $\begin{array}{c}1 \\
1 \%\end{array}$ & $\begin{array}{c}1 \\
1 \%\end{array}$ & & $\begin{array}{c}8 \\
7 \%\end{array}$ & & & & & & & & & \\
\hline Generalization & & & & & $\begin{array}{c}6 \\
5 \%\end{array}$ & & & & & & & & \\
\hline Specification & & & & & & $\begin{array}{c}5 \\
4 \%\end{array}$ & & & & & & & \\
\hline Co-Specification & & & & & & & $\begin{array}{c}3 \\
3 \%\end{array}$ & & & & & & \\
\hline Contrast & & & & & & & & $\begin{array}{c}3 \\
3 \% \\
\end{array}$ & & & & & \\
\hline
\end{tabular}


Table 5

"The Cask of Amontillado" Translated to be "Tong Anggur" by Anton Kurnia

\begin{tabular}{|c|c|c|c|c|c|c|c|c|c|c|c|c|c|}
\hline \multirow[b]{2}{*}{$\begin{array}{l}\text { Lexical } \\
\text { Cohesion } \\
\text { Devices }\end{array}$} & \multirow[b]{2}{*}{ 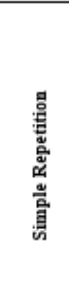 } & \multirow[b]{2}{*}{ 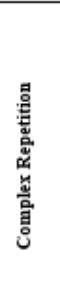 } & \multicolumn{3}{|c|}{ Reiteration } & \multirow[b]{2}{*}{ 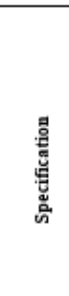 } & \multirow[b]{2}{*}{ 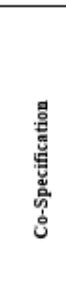 } & \multirow[b]{2}{*}{ 兽 } & \multicolumn{3}{|c|}{ Collocation } & \multicolumn{2}{|c|}{ Lexical Chain } \\
\hline & & & $\begin{array}{l}\text { 量 } \\
\text { 䯵 } \\
\text { 密 }\end{array}$ & 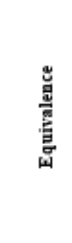 & 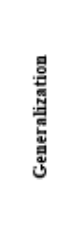 & & & & 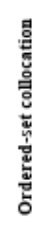 & 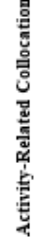 & 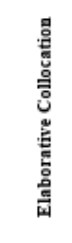 & $\begin{array}{l}\text { 昜 } \\
\text { 意 } \\
\text { 晋 }\end{array}$ & $\begin{array}{l}\text { 量 } \\
\text { 齿 } \\
\text { 意 }\end{array}$ \\
\hline Reiteration & & & & & & & & & & & & & \\
\hline $\begin{array}{c}\text { Simple } \\
\text { Repetition }\end{array}$ & $\begin{array}{l}16 \\
13 \\
\%\end{array}$ & & $\begin{array}{c}2 \\
2 \%\end{array}$ & $\begin{array}{c}1 \\
1 \%\end{array}$ & & $\begin{array}{c}1 \\
1 \%\end{array}$ & $\begin{array}{c}1 \\
1 \%\end{array}$ & & & & & & \\
\hline $\begin{array}{c}\text { Complex } \\
\text { Repetition }\end{array}$ & $\begin{array}{c}1 \\
1 \%\end{array}$ & & & & & & & & & & & & \\
\hline Substitution & & & $\begin{array}{c}8 \\
7 \%\end{array}$ & & & & & & & & & & \\
\hline Equivalence & $\begin{array}{c}2 \\
2 \%\end{array}$ & & $\begin{array}{c}1 \\
1 \%\end{array}$ & $\begin{array}{c}3 \\
3 \%\end{array}$ & & $\begin{array}{c}2 \\
2 \%\end{array}$ & & & & & $\begin{array}{c}1 \\
1 \%\end{array}$ & & $\begin{array}{c}1 \\
1 \%\end{array}$ \\
\hline Generalization & $\begin{array}{c}1 \\
1 \%\end{array}$ & & & & $\begin{array}{c}5 \\
4 \%\end{array}$ & & & & & & & & \\
\hline Specification & $\begin{array}{c}1 \\
1 \%\end{array}$ & & & & & $\begin{array}{c}3 \\
3 \%\end{array}$ & & & & & & & \\
\hline Co-Specification & & & & & & & $\begin{array}{c}2 \\
2 \%\end{array}$ & & & & & & \\
\hline Contrast & & & & & & & & $\begin{array}{c}3 \\
3 \%\end{array}$ & & & & & \\
\hline
\end{tabular}

Table 6

Result

\begin{tabular}{ccc}
\hline & $\begin{array}{c}\text { Translated Reiteration } \\
\text { In "The Black Cat" }\end{array}$ & $\begin{array}{c}\text { Translated Reiteration } \\
\text { In "The Cask of Amontillado" }\end{array}$ \\
\hline Anton Kurnia & $44 \%$ & $50 \%$ \\
Shinta Dewi & $57 \%$ & $66 \%$ \\
\hline
\end{tabular}

\section{CONCLUSION}

Lexical cohesion is much closed to texts since it can give cohesion as well as continuity of the ideas in the text. Every writer must be aware of the importance of lexical cohesion, so do the translators. Based on the analyses in the previous chapter and according to the problems of the study arised, this thesis comes to a conclusion:

All kinds of lexical cohesion devices can be found in the short stories entitled "The Black Cat" and "The Cask of Amontillado" written by Edgar Allan Poe. The most widely applied lexical cohesion devices were simple repetition, substitution, and elaborative collocation. Other kinds of lexical cohesion found in the short stories "The Black Cat" and "The Cask of Amontillado" were equivalence, identity and similarity chain, generalization, specification, substitution, activity-related collocation, co-specification, complex repetition, ordered-set collocation, and contrast.

Different methods applied will affect the translation of lexical cohesion devices in the target language. Anton Kurnia translated less lexical cohesion devices in the source language compared to Shinta Dewi. Anton Kurnia, who mostly applied communicative and free translation methods translated $47 \%$ of reiteration into reiteration and another types of lexical cohesion devices. Meanwhile, Shinta Dewi, who applied more literal translation methods, translated $62 \%$ of reiteration to be reiteration and other types of lexical cohesion devices in the target language.

The analyses elaborated in this study can be an illustration to those who also want to do a translation works, in this case, literary works in order to find the right methods to translated lexical cohesion devices and achieve a high readability. They must decide whether they want to choose translation methods oriented toward a source language or target language. Both orientations will affect the quality of the translation products which determine the translated text readability. 


\section{REFERENCES}

Catford, J. C. (1965). A Linguistic Theory of Translation.An Essay in Applied Linguistics. London: Oxford University Press.

Halliday, M. A. K., \& Hasan, R. (1976). Cohesion in english. London: Longman Group Ltd.

Halliday, M. A. K., \& Hasan, R. (1985). Language, context and text: aspects of language in a social semiotic perspective. Oxford: Oxford University Press.

Larson, M. J. (1998). Meaning-Based Translation Studies. London: Routledge.

Lotfipour-Saedi, K. (1997). Lexical Cohesion and Translation Equivalence. ERUDIT, 42(1), 185-192. Retrieved from https:// doi.org/10.7202/004014ar

Morris, J., \& Hirst, G. (1991). Lexical cohesion computed by thesaural relations as an indicator of the structure of text. Computational Linguistics, 17(1), 21-48.

Nassar, H. A. (2014). Lexical Cohesion in the Translation of "Pride and Prejudice". Yordania: Zarqa University

Newmark, P. (1988). A Textbook of Translation. Hong Kong: Prentice $\mathrm{HaH}$ International vUIO Ltd.

Poe, E. A. (2004). Kucing Hitam. Bandung: Nuansa.

Tanskanen, .K. (2006). Collaborating towards Coherence. Philadelphia: John Benjamins B.V.

Webster's Collegiate Dictionary. (1993). USA. 